\title{
Quo Vadis Melanesian Spearhead Group?
}

\author{
Baiq L.S.W. Wardhani \\ Departemen Hubungan Internasional FISIP Universitas Airlangga
}

\begin{abstract}
ABSTRAK
Menguatnya sentimen identitas di dalam Melanesian Spearhead Group (MSG) bersamaan dengan kecenderungan melemahnya kapabilitas kemandirian untuk melakukan tata kelola domestik merupakan salah satu faktor yang menyebabkan berubahnya dinamika di Pasifik Selatan. Salah satunya ditandai dengan menguatnya kekhawatiran bahwa negara-negara di dalam kelompok ini semakin sulit melepaskan diri dari ketergantungan terhadap bantuan luar negeri. Menguatnya sentimen identitas secara empiris dapat diamati dari pergolakan di dalam organisasi tersebut, yang menunjukkan bahwa para anggotanya semakin tidak khawatir pada perbedaan pendapat di antara mereka. Sementara itu lemahnya kapabilitas mengelola secara mandiri persoalan domestik ditunjukkan dengan meningkatnya bantuan finansial dari negara donor. Padahal pada saat yang bersamaan krisis di negara donor dan relatif menurunnya urgensi Pasifik Selatan dalam geopolitik negara-negara donor dapat membawa organisasi regional ini dalam posisi limbo. Alternatif jalan keluar telah diambil, namun menimbulkan pertanyaan, mau dibawa ke manakah MSG?
\end{abstract}

Kata-kata kunci: Melanesian Spearhead Group, Regionalisme, Pasifik Selatan.

Strengthening the sentiment of identity in the Melanesian Spearhead Group (MSG) in conjunction with a weakening of self-reliance capability to undertake domestic governance is one of the factors that caused the change in dynamics in the South Pacific. One was marked by the strengthening fears that the countries in this group is increasingly difficult to break away from dependence on foreign aid. Strengthening sentiment can be observed from the upheaval of identity among the members within the organization, which showed that its members are increasingly worried about the disagreements between them. While the weak capability to independently manage domestic issues indicated by the increasing financial assistance from donor countries. Yet at the same time a crisis in donor countries and the relative decline in the South Pacific in geopolitical urgency from the perspective of the donor countries can bring this regional organization in limbo. Alternative way out has been taken, but which way will be taken by the MSG?

Keywords: Melanesian Spearhead Group, Regionalism, South Pacific. 
Sebagai wilayah yang jauh dari pusat keramaian dunia, Pasifik Selatan tidak terlalu dikenal oleh kebanyakan orang. Letaknya yang terpencil, bentuknya yang tersebar, luas wilayahnya yang terbatas (kecuali Papua New Guinea), menjadikan kawasan ini luput dari arus utama kajian hubungan internasional, politik global dan regionalisme. Sekali pun demikian, Pasifik menyimpan sejumlah persoalan menarik yang tidak kalah pentingya dengan kawasan-kawasan lain. Bahkan karena berbagai keterbatasan yang dimilikinya, Pasifik Selatan memiliki keunikan yang menawarkan 'surga' bagi para peneliti. Secara khusus tulisan ini mengulas tentang Melanesian Spearhead Group (MSG) yang merupakan salah satu wujud regionalisme di Pasifik Selatan. Argumen yang dikemukanan adalah, MSG menandai berkembangnya regionalisme di Pasifik Selatan yang menunjukkan pergeseran fokus dan kepentingan, dari organisasi yang eksistensialitas dengan mengutamakan faktor identitas menjadi organisasi yang lebih esensialitas-pragmatis dengan pertimbangan survivalitas yang lebih besar. Pergeseran tersebut menimbulkan sejumlah konflik internal dalam organisasi-organisasi regional di Pasifik Selatan. Kemampuan mengelola konflik di antara mereka akan menentukan bagaimana hubungan intraregional berlangsung.

\section{Evolusi Regionalisme di Pasifik Selatan}

Terdapat delapan organisasi regional utama di Pasifik Selatan, yaitu The Pacific Islands Forum (PIF), the Forum Fisheries Agency (FFA), the Secretariat of the Pacific Community (SPC), the South Pacific Regional Environment Programme (SPREP), the South Pacific Applied Geoscience Commission (SOPAC), The University of the Pacific (USP), the South Pacific Tourism Organization (SPTO), and the Pacific Island Development Programme (PIDP) (UNESCAP 2000). MSG tidak pernah disebut-sebut sebagai salah satu organisasi regional di kawasan itu karena pada awalnya MSG hanyalah oragnisasi informal dari sejumlah negara di sub-kawasan Melanesia yang berdiri pada tahun 1988. Pada tahun 2008, MSG secara resmi diakui keberadaanya secara hukum internasional.

Tidak seperti organisasi-organisasi regionalisme yang berkembang di kawasan-kawasan lain, sejarah regionalisme di Pasifik Selatan ditandai dengan beberapa hal. Pertama, regionalisme di kawasan tersebut diwarnai oleh nuansa identitas dan rivalitas yang kuat, bahkan mendominasi hubungan intra sub-kawasan, yaitu antara Melanesia, Polynesia dan Micronesia. Diplomasi yang berlangsung di antara negara-negara kecil di kawasan ini mengambil bentuk yang unik, yaitu bercirikan non-formal dan relatif egalitarian. Contohnya, beberapa organisasi regional tidak membedakan status kemerdekaan untuk menjadi anggotanya. 
Kedua, kerjasama regional yang dibangun tidaklah terlalu berkaitan dengan pendekatan market-sharing sebagaimana yang dialami oleh kebanyakan negara (perdagangan bebas, kepabean, pengembangan sektor perbankan, perencanaan industri). Pendekatan yang digunakan dalam menginisiasi kerjasama lebih didorong oleh faktor ketersebaran geografis, keterpencilan, ketidakberdayaan ekonomi, dan kurangnya sumber daya. Inilah yang menjadi isu keamanan fundamental di Pasifik Selatan, bukan musuh eksternal (baca: serangan dari negara lain) dan persoalan yang berkaitan dengan batas wilayah teritorial. Kondisi demikian memaksa negara-negara di kawasan ini memilih mekanisme kerjasama regional yang berorientasi untuk mencapai tujuan-tujuan khusus yang secara langsung berkontribusi terhadap tujuan-tujuan pembangunan nasional negara-negara anggotanya. Kerjasama regional memberikan mereka kesempatan untuk berbagi jasa dan fasilitas bersama dengan biaya yang sangat efektif. Negara-negara Pasifik berbagi dalam hal fasilitas diplomatik karena hampir tidak mungkin mereka melakukannya secara individual. Misalnya, fasilitas kantor PBB di New York (yang dibiayai oleh Australia) digunakan secara bersama oleh beberapa negara Pasifik Barat Daya (Fairbairn 1991).

Ketiga, kerjasama regional di Pasifik Selatan secara fungsional dibentuk untuk "amplifying their voices". Sebagai akibat dari faktor-faktor yang telah disebutkan di atas (ketersebaran geografis, keterpencilan, ketidakberdayaan ekonomi, dan kurangnya sumber daya), negaranegara di Pasifik Selatan hampir tidak pernah diperhatikan oleh dunia internasional. Organisasi regional di wilayahnya sangat membantu dalam mengartikulasikan kepentingan mereka dan secara kolektif Negara-negara tersebut akan lebih diperhatikan apabila mereka bersuara bersama. Kekuatan mereka secara berkelompok akan memberi kekuatan pada posisi tawar mereka atas berbagai isu. Mereka juga memiliki kesempatan untuk mendapatkan manfaat lain yang lebih besar daripada mereka melakukannya secara sendiri-sendiri.

Keempat, masih berkaitan dengan faktor ketiga, bahwa regionalisme di Pasifik Selatan, di tengah perbedaan yang ada, memberikan rasa persatuan (sense of unity) yang berdasarkan pada keterkaitan antara tradisi, kepentingan dan sudut pandang bersama. Faktor ini menandai pentingnya difahami ideologi "Pacific Way" yang merefleksikan gaya konsensus non-konfrontasi dalam melaksanakan diskusi dan mencapai kesepakatan (Fairbairn 1991). Konsensus ini dapat diinterpretasikan sebagai wujud dari keinginan non-intervensi yang ditujukan kepada negara-negara metropolitan yang selama ini menjadi negara donor utama bagi mereka. Selain itu sikap yang tercermin dalam Pacific Way yang merupakan aspirasi untuk mengurangi ketergantungan kepada negara-negara donor. 
Perkembangan regionalisme di Pasifik Selatan diwarnai oleh dua organisasi utama. Dua organisasi ini merupakan dua mekanisme penting dalam menyuarakan berbagai kepentingan negara-negara anggotanya. Pertama, South Pacific Commission (SPC) yang bersifat non-politis, yang didirikan tahun 1947, jauh sebelum negara-negara Pasifik merdeka, yang beranggotakan Prancis, AS, dan Inggris. SPC dianggap sebagai organisasi yang mewakili suara negara-negara metropolitan yang pernah menguasai negara-negara di Pasifik Selatan. Kedua, Pacific Island Forum/PIF (pada awalnya bernama South Pacific Forum/SPF), yang bersifat lebih 'indigenous' yang berdiri pada tahun 1971. PIF didirikan sebagian disebabkan oleh keputusasaan akibat sulitnya pembahasan masalah dekolonisasi di forum SPC (Frazer, Ian and Bryant-Tokalau, nd).

Sekalipun belum diakui secara resmi oleh hukum internasional, pada tahun 1972, SPF membentuk sekretariat permanen, yang pada awalnya disebut South Pacific Economic Cooperation (SPEC), yang sekarang disebut Sekretariat Forum. Sesuai dengan maksud didirikanya, tujuan awal SPEC adalah untuk mengkoordinasikan kegiatan perdagangan antara negara-negara anggota dan bertindak sebagai clearing house informasi. Namun dalam perkembangan selanjutnya SPEC menjalankan tanggung jawab yang lebih besar daripada sekedar koordinator perdagangan. Merasa bahwa fungsi SPF tidak maksimal dan masih tingginya intervensi negara-negara metropolitan, Papua New Guinea dan beberapa negara Melanesia lainnya mengusulkan gagasan "Single Regional Organization" yang menggabungkan fungsi SPC ke SPF dan Sekretariat Forum dan tidak mengikutsertakan kekuatan metropolitan. Ide Papua New Guinea tersebut sebenarnya merupakan penguatan kembali pernyataan ratu Sir Kamisese Mara pada pertemuan di Lae, Papua New Guinea pada tahun 1965 yang menghendaki perubahan struktur dalam SPC dengan mengurangi dominasi negara-negara kolonial. Ide tersebut belum bisa diwujudkan sampai tahun 1980-an karena tidak mendapatkan dukungan dari beberapa anggota karena beberapa negara anggotanya berkepentingan mempertahankan SPC dan SPF sebagai dua lembaga yang terpisah (Shibuya, nd). Sikap menolak ini dilakukan oleh beberapa negara-negara kepulauan kecil tidak mau mengambil risiko bantuan atau hubungan ekonomi mereka bermasalah dengan Inggris, Prancis dan Amerika Serikat.

Sementara terdapat ketidaksepakatan tentang organisasi regional tunggal, pada tahun 1987 Forum Pasifik Selatan membentuk Committee on Regional Institutional Arrangements. Badan ini berfungsi sebagai penengah dalam melakukan dengan fihak eksternal, seperti menjadi pengatur dialog antara kekuatan tradisional metropolitan (Prancis, Inggris dan Amerika Serikat), dan kekuatan Pasifik lainnya seperti Jepang, China dan Kanada. Namun, Forum Pasifik Selatan, badan 
regional utama yang menyuarakan isu-isu politik, terus menjadi badan ad hoc. Sekalipun melakukan pertemuan tahunan kepala negara, FPS berjalan tanpa status hukum internasional yang proper karena badan tersebut tidak pernah dibentuk melalui perjanjian atau charter formal (ANU 2011).

Peranan PIF mengalami penguatan dari waktu ke waktu seiring dengan berkembangnya berbagai isu global, yang Pasifik Selatan tidak luput dari perkembangan isu-isu tersebut. Sebagai organisasi regional, PIF diharapkan mampu menjadi wadah aksi kolektif bagi anggotanya. Sekali pun demikian laju perkembangan isu-isu global melebihi laju kemampuan PIF untuk mengatasinya sehingga PIF terkesan lambat dalam merespon berbagai isu tersebut. Sebaliknya, PIF lebih disibukkan dengan berbagai konflik dan ketegangan yang terjadi di beberapa negara anggotanya. Seiring dengan menurunnya kondisi dalam negeri Fiji, kegiatan PIF mengalami penurunan karena Sekretariat PIF terletak di Suva, ibukota Fiji. Kudeta di Fiji menyebabkan keanggotaan negara ini di PIF ditangguhkan sampai batas waktu yang tidak ditentukan sambil menunggu pulihnya stabilitas domestik.

Kelahiran MSG dalam sub-kawasan Melanesia menimbulkan spekulasi tentang "persaingan" antara PIF dengan MSG. Seperti yang dituliskan oleh Tarte $(2014,313)$, terdapat perbedaan opini mengenai hadirnya MSG, yng di sati fihak dianggap "fill a gap in the region's architecture, but do not challenge the dominant position and authority of the PIF', namun di fihak lain that 'it seems unlikely that the MSG or some other MSG Plus grouping poses a serious challenge to the Pacific Islands Forum'. Berbagai opini tersebut tidak mengubah kenyataan bahwa pada saat ini terdapat organisasi regional yang lebih beragam di Pasifik Selatan, yang menandai semakin meningkatnya dinamika kawasan tersebut. Hal ini menunjukkan bahwa Pasifik Selatan menunjukkan komitmen yang lebih tinggi dalam menyelesaiakan persoalan-persoalan di kawasan sekaligus merupakan upaya mengurangi ketergantungan dari negara-negara metropolitan.

\section{MSG dan Sentimen Identitas}

Kelahiran MSG yang merupakan organisasi regional terbaru di Pasifik Selatan telah mewarnai arsitektur baru dalam regionalisme di Pasifik Selatan. Organisasi ini didirikan di Port Vila pada 14 Maret 1988 oleh kepala pemerintahan dari masing-masing negara merdeka (Papua New Guinea, Vanuatu, Solomon Island) dan perwailan FLNKS (Front de Liberation Nationale Kanak et Socialiste - FLNKS, gerakan prokemerdekaan di Kaledonia Baru. Sementara itu Fiji bergabung pada tahun 1998. Setelah sembilan tahun sejak didirikan, pada tahun 2007 
MSG ditetapkan sebagai lembaga resmi yang diakui dalam hukum internasional.

Kehadiran kelompok politik seperti FLNKS merupakan hal yang tidak biasa dalam organisasi regional yang biasanya hanya menerima negara berdaulat sebagai anggotanya. Bergabungnya kelompok etnis ini mencerminkan akar sejarah dan politik dari MSG yang didasari oleh semangat solidaritas etnis dan budaya dengan komitmen untuk membantu membebaskan sesama bangsa Melanesia yang dianggap masih berada dalam kolonialisme. Solidaritas ini menandai pentingnya, bahkan menjadi motivasi utama penandatanganan 'Prinsip Persetujuan Kerjasama antara negara-negara Melanesia Merdeka' pada tahun 1988. Kehadiran MSG menimbulkan pertanyaan akan tumpang tindihnya organisasi ini dengan PIF karena tiga negara anggota MSG (Papua New Guinea, Solomon Islands, dan Vanuatu) juga merupakan anggota PIF. Bahkan beberapa staf di Sekretariat MSG juga merupakan staf di Sekretariat PIF dan beberapa organisasi regional lainnya di kawasan itu (The Lowy Interpreter 2014)

Salah satu hal yang khas adalah, faktor identitas memberi pengaruh yang penting dalam perkembangan regionalisme di Pasifik Selatan. Sekali pun tidak menjadi bahasan penting dalam mainstream hubungan internasional, identitas memberi pengaruh signifikan dalam menentukan percaturannya dalam politik global. Elemen-elemen identitas seperti "we feelings", persamaan sejarah dan kemiripan sistem nilai dan budaya, dapat menjadi landasan kuat bagi kemungkinan keberhasilan atau kegagalan organisasi regional. Dalam beberapa kasus, "we feelings" mampu menjadi perekat di antara mereka, misalnya tentang isu nuklir (di masa Perang Dingin), atau penolakan Australia meratifikasi Protokol Kyoto pada awal tahun 2000-an. Penolakan ini menyebabkan negara-negara Pasifik Selatan geram karena sikap Australia tersebut dianggap arogan dan tidak bertanggngjawab.

Pasifik Selatan memperlihatkan keberagaman kultural yang cukup besar. Contohnya, Polynesia tidak hanya dipisahkan oleh masalah kultural dan perbedaan linguistik tetapi juga tingkat perkembangan yang berbeda, yang mencerminkan perbedaan dalam kesempatan proses 'westernisasi'. Orang-orang Polynesia (yang mewakili 'the east'), diidentifikasikan sebagai 'the advanced'; Sementara orang-orang Melanesia (yang mewakili 'the west') acap kali didentifikasikan sebagai 'the backward'. Menariknya, Fiji, yang diklasifikasikan sebagai Melanesian, dipandang sebagi bagian dari the east, berdasarkan pada organisasi sosial, tingkat pendidikan, pembangunan politik dan keterkaitan sosialnya dengan Samoa and Tonga (Lawson 2012, 4-5). 
Nilai-nilai identitas yang tertanam cukup kuat di Melanesia tidak terlepas dari peran tokoh-tokoh intelektual di wilayah tersebut seperti mendiang Bernard Narokobi, Jean Marie Tjibaou dan Walter Lini. Mereka membangun nilai-nilai umum dan identitas yang membuat Melanesia sebagai kelompok etnis yang khas di dunia. Identitas Melanesia yang didukung oleh para pemikir besar memiliki tempat dalam menciptakan kesadaran dari berbagai tantangan yang mereka hadapi. Terkandung dalam aspirasi para pemimpin tersebut untuk membuat Pasifik Selatan sebagai wilayah yang dikenal dalam perpolitikan dunia. Sebagai contoh, Walter Lini adalah Perdana Menteri pertama Vanuatu yang dikenal beraliran radikal. Sejak awal kemerdekaan Vanuatu, PM Lini telah menjalin hubungan dengan kelompok-kelompok radikal dan negara-negara yang memiliki pemimpin radikal, seperti Presiden Khadafi. PM Lini juga mengizinkan negaranya digunakan sebagai basis bagi gerakan-gerakan pemisahan diri. Sikap radikal yang ditunjukkan oleh para pemimpin terdahuku Vanuatu hingga saat ini masih dilaksanakan.

Sikap luar negeri Vanuatu, dalam banyak hal sering menyebabkan konflik dengan Indonesia. Vanuatu sering memiliki pendirin yang berbeda dengan Indonesia, khususnya dalam menyikapi gerakan pemisahan diri di Papua/Irian Jaya. Secara terang-terangan Vanuatu menunjukkan sikap menolak setiap langkah yang diambil Indonesia ketika Indonesia mendapatkan simpati dari fihak lain. Sikap diametral ini seolah-olah telah menjadi platform yang diambil oleh Vanuatu untuk setiap persoalan yang berkaitan dengan gerakan Organisasi Papua Merdeka (OPM). Kecenderungan untuk selaku memberikan dukungan bagi gerakan pemisahan diri OPM menunjukkan sentiment etnis yang tinggi pada sesama kelompok etnis. Sikap Vanuatu menunjukkan kecenderungan nepotisme etnik. Nepotisme etnik terjadi pada situasi konflik etnis, yang menggembarkan pertentangan yang berkaitan dengan ketidakstabilan dan saling bertentangan dalam hubungan yang terjadi antara berbagai etnis yang diwarnai dengan ikatan primordial, budaya, suku, ras, bahasa, kasta dan komunal yang digunakan (Vanhanen 1999, 55). Situasi ini terjadi dalam hubungan Indonesia dengan Vanuatu yang secara konsisten mendukung OPM. Terdapat kecenderungan bahwa persamaan etnis yang terdapat di dua negara yang berbeda dapat menyebabkan hubungan konfliktual antara dua negara tersebut. Terlebih lagi jika salah satu etnis dipersepsikan mengalami opresi di negara "seberang', maka dukungan bagi etis yang teropresi tersebut semakin besar. Gejala ini dijelaskan oleh Saideman $(2002,1)$ sebagai "discrimination in international relations". Hal ini merupakan gejala umum yang tidak hanya terjadi antara Indonesia dengan Vanuatu, namun dapat ditemukan di beberapa hubungan antarnegara lain juga. Menurutnya, "groups with ethnic ties to actors in 
positions of power elsewhere are more likely to receive external assistance.”

Nepotisme etnik dan diskriminasi dalam hubungan internasional setidaknya bisa menjelaskan sikap Vanuatu yang dalam banyak hal bertentangan dengan Indonesia dalam persoalan kemerdekaan Papua. Seperti telah diketahui bahwa, sekalipun terlambat, sejak tahun 1980-an Indonesia berupaya mendekatkan diri ke Pasifik Selatan. Catatan sejarah hubungan Indonesia dengan negara-negara di wilayah ini menunjukkan rekam jejak yang tidak menggembirakan. Persoalan utama yang muncul berpusat pada image negatif negara-negara Pasifik Selatan yang melihat Indonesia sebagai negara 'agresif' karena peliknya persoalan nation building yang tidak terlepas dari masalah etnisitas di Indonesia, khususnya yang terjadi di Indonesia timur. Wilayah paling timur Indonesia merupakan rumah yang dihuni sebagian besar oleh etnis Melanesia (Papua/Irian Jaya, Maluku, Nusa Tenggara Timur, dan Timor Timur di masa lalu). Jumlah mereka bahkan lebih banyak dari jumlah gabungan penduduk Melanesia di Pasifik Selatan.

Negara-negara Pasifik Selatan, seperti Vanuatu, Tonga, Samoa, dan sesekali Papua New Guinea, kerap kali menunjukkan sikap yang tidak bersahabat di berbagai forum internasional, termasuk PBB. Setelah kepemimpinan Presiden Suharto, para pemimpin nasional mencoba melakukan pendekatan melalui cara-cara formal kelembagaan, seperti membentuk Southwest Pacific Dialogue pada masa Presiden Abdurrahman Wahid maupun informal dengan mengirimkan misi-misi budaya. Langkah-langkah untuk menciptakan rasa percaya terus ditingkatkan sampai akhirnya Indonesia berhasil menjadi pengamat di dalam PIF dan MSG. Langkah maju yang dicapai Indonesia dalam melembagakan hubungannya dengan wilayah tersebut adalah dengan diterimanya Indonesia menjadi anggota resmi dalam MSG pada 26 Juni 2015 yang bertepatan dengan KTT MSG di Honiara, ibukota negara Solomon Islands. Sementara itu, United Liberation Movement for West Papua (ULMWP) mendapat status sebagai peninjau, sekali pun yang sejak 2013 organisasi yang berafiliasi dengan OPM ini selalu mencoba untuk diterima sebagai anggota resmi MSG.

Bergabungnya Indonesia secara resmi menjadi anggota MSG dan belum terdapatnya kesepakatan tentang keanggotaan WPNCL menandai perbedaan pendapat di dalam MSG. Silang pendapat tentang keanggotaan Indonesia dan WPNCL sudah muncul pada tahun 2013. Tidak seperti WPNCL, penerimaan resmi keanggotaan FLNKS tidak mengalami kendala. Hal inilah yang menyebabkan gesekan di dalam tubuh MSG. Seperti yang telah dinyatakan di atas, sementara Vanuatu mengambil sikap asertif, Papua New Guinea, Fiji memiliki hubungan yang lebih signifikan dengan Indonesia, dan karenanya mendukung 
keanggotaan Indonesia dalam regionalisme baru tersebut. Sementara itu Solomon Islands tidak secara tegas menyatakan posisinya. Dampak perpecahan di dalam MSG menimbulkan berbagai kekhawatiran, seperti dilemma moral, redifinisi ke-Melanesia-an, dan dominasi Indonesia, seperti dinyatakan oleh Kabutaulaka (2015) di Vanuatu Post Daily,

...if the MSG leaders deny the ULMWP membership, it could widen the rift between MSG countries. It could also redefine Melanesia, blur the cultural and political divisions between Oceania and Southeast Asia, and see a Melanesian sub-region dominated by Indonesia. The MSG leaders are therefore faced with the difficult task of balancing, on one hand, their moral obligation to support Melanesians in West Papua, and on the other hand, respecting Indonesia's sovereignty...

Identitas yang bertumpangtindih dengan persoalan kedaulatan telah menjelma menjadi fokus yang produktif dan mudah dieksploitasi di Melanesia. Secara historis, tiga negara ini relatif konsisten mendukung posisi Indonesia dalam isu-isu yang berkaitan dengan pemisahan diri Papua. Sikap ini tercermin dalam pernyataan resmi para pemimpinnya yang disampaikan dalam berbagai forum internasional. Memiliki persamaan dalam hal nation building, Papua New Guinea, misalnya, memilih untuk tidak mendukung Organisasi Papua Merdeka. Konsistensi Papua New Guinea untuk menghormati kedaulatan teritorial Indonesia merupakan keputusan yang menghendaki sikap yang sama dari Indonesia untuk menjaga kedaulatan Papua New Guinea. Perbatasan artifisial antara Indonesia dan Papua New Guinea berpotensi rawan konflik. Beberapa insiden yang terjadi antara Indonesia dan Papua New Guinea pada tahun 1980-an menunjukkan bahwa terdapat persoalan territorial antara kedua negara. Rawannya masalah perbatasan dan keinginan kuat dari Indonesia dan Papua New Guinea untuk mengelola konflik perbatasan dapat menjadi alasan kuat dua negara untuk bekerjasama lebih erat.

\section{Pergeseran lansekap MSG?}

Persoalan mendasar yang dihadapi oleh negara-negara Pasifik Selatan adalah menyangkut survivalitasnya menghadapi berbagai perubahan penting dalam persoalan-persoalan global. Pacific Island Forum mencoba untuk mengakomodasikan kepentingan-kepentingan politik dan ekonomi negara-negara anggotanya, namun berbagai kendala telah membuat organisasi regional ini tidak berfungsi maksimal. Sementara itu kejadian-kejadian yang melanda beberapa negara-negara seperti pemberontakan di Bougainville, kudeta $(1979,1999,2006)$ dan ketidakharmosisan hubungan rasial di Fiji, ketegangan etnis di Solomon Islands dan konflik elit di Vanuatu, dan buruknya penegakan hukum 
dan ketertiban merupakan masalah yang merepresentasikan kompleksitas di Pasifik Selatan seingga kawasan ini sering disebut sebagai "arc of instability" yang dikhawatirkan menuju pada kondisi negara gagal. Negara-negara Melanesia harus menyelesaiakan persoalannya sehingga tidak terjebak dalam stigma negara gagal tersebut.

Berlanjutnya hubungan konfliktual, baik di dalam negara maupun antarnegara bukanlah pilihan rasional Pasifik Selatan untuk survive. Penggunaan keluatan militer untuk menyelesaikan konflik dan krisis tersebut juga bukan pilihan tepat karena pilihan tersebut tidak sustainable dan bahkan kemungkinan justru mengundang fihak eksternal untuk mengambil keuntungan. Negara-negara mampu mentransformasikan hubungan konfliktual menjadi lebih bermanfaat dengan pendekatan yang lebih fungsional, yaitu dalam bentuk kerjasama. Mengikuti logika kaum fungsionalis, stabilitas jangka panjang dapat dilakukan dengan bekerjasama yang saling menguntungkan untuk mengatasi persoalan-persoalan regional. Dalam kalimat sederhana, Kaiku (2013) mengatakan, "bounded by parochial world-views, Melanesians will not find any common ground in addressing challenges in their neighborhood". Ada saatnya ketika identitas dibangun untuk memberi makna dan rasa persatuan di antara sesama negara Pasifik, khususnya Melanesia. Akan tetapi hal ini terbukti tidak dapat menjadi solusi atas masalah-masalah mendesak.

Salah satu persoalan mendesak yang berkaitan dengan survivalitas adalah adalah mengatasi ketergantungan bantuan kepada fihak asing, terutama Amerika Serikat. Pasifik Selatan merupakan kelompok regional yang paling banyak menerima bantuan pembangunan asing, terutama dari negara-negara metropolitan. Sebagian besar negara di kawasan menjadikan bantuan asing sebagai sumber utama pendapatan negara. Strategi ini tentu tidak apat diandalkan keberlangsungannya karena berbagai alasan dari negara donor. Negara-negara metropolitan, misalnya memberi bantuan yang cukup besar pada masa baru diberikannya kemerdekaan kepada negara-negara Pasifik, namun sedikit demi sedikit mengurangi jumlahnya. 


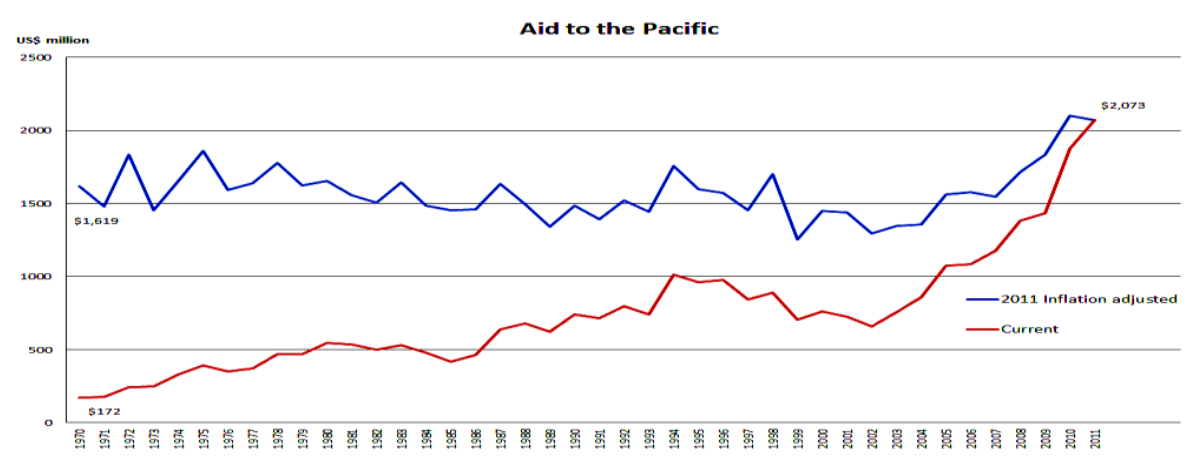

Sumber: Jonathan Pryke, 2013. http://devpolicy.org

Secara umum, kecenderungan penurunan dan kenaikan bantuan (aid) yang dikucurkan ke Pasifik dapat dijelaskan dengan melihat dinamika yang terjadi di kawasan tersebut. Tingginya bantuan luar negeri disebabkan karena negara-negara metropolitan memiliki kewajiban untuk membantu proses dekolonisasi di Pasifik Selatan, yang berlangsung pada tahun 1960-an. Bantuan pembangunan terus diterimakan dalam rangka penguatan kelembagaan dan membangun infrastuktur dan keberlangsungan proses nation-building. Bantuan jenis ini adalah bantuan 'normal dan rutin'. Namun terdapat hal yang menarik di dalam grafik, yaitu meningkatnya bantuan sejak pertengahan tahun 2000.

Terdapat setidaknya dua penjelasan mengenai kenaikan bantuan. Pertama, kenaikan terjadi pada negara-negara yang menjadi target tradisional bantuan luar negeri Australia, namun tidak terjadi pada negara-negara target tradisonal AS (Pryke 2013). Besarnya bantuan tersebut difokuskan untuk mengatasi persoalan domestik di beberapa negara yang bermasalah, seperti Solomon Islands, Fiji, dan Papua New Guinea. ${ }^{1}$ Kecuali bantuan rutin ke Papua New Guinea, bantuan-bantuan ke Fiji dan Solomon dapat dikategorikan sebagai 'non-rutin' sebagai respon Australia atas konflik-konflik internal di negara-negara tersebut. Bantua non-rutin juga diberikan ke negara-negara yang beberapa tahun belakangan dilanda bencana alam, seperti banjir di Fiji dan Kiribati, badai Evan di Samoa, tsunami di Tonga, dan sebagainya. Kenaikan jumlah bantuan juga terjadi pada ke negara-negara yang dekat dengan New Zealand seperti Cook Islands, Nauru, Niue, Samoa, Tonga, dan Tuvalu (Pryke 2013). Kedua, terdapatnya para pendonor baru selain pendonor tradisional, yaitu negara-negara Teluk, China dan Indonesia

\footnotetext{
${ }^{1}$ Papua New Guinea merupakan perkecualian dalam bantuan luar negeri Australia. Selain menrima bantuan untuk mengatasi pemberontakan di Bougainvilla, Papua New Guinea adalah penerima bantuan terbesar sejak negara ini merdeka tahun 1975 .
} 
dan organisasi internasional. Secara keseluruhan, bantuan yang diterima oleh negara-negara Pasifik dan para pendonornya digambarkan sebagai berikut

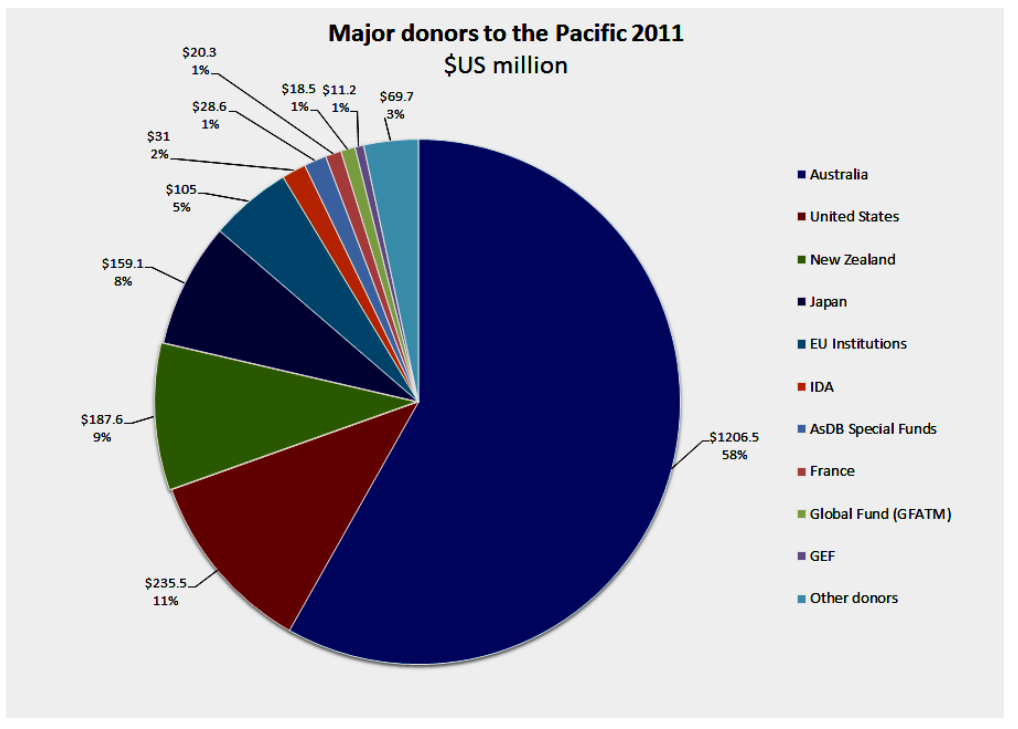

Sumber: Jonathan Pryke, 2013. http://devpolicy.org

Tingkat ketergantungan yang tinggi, terutama bantuan rutin dan normal kepada bantuan luar negeri bukanlah strategi survival yang berkelanjutan (sustainable). Skema perekonomian di Pasifik yang disebut MIRAB (Migration, Remittances, Aid and Bureaucracy), sekali pun masih signifikan, tidak lagi dapat menggambarkan sepenuhnya kecenderungan yang terjadi di Pasifik, terutama dari aspek aid. Ketergantungan pada bantuan luar negeri bahkan menjadi tumpuan utama bagi beberapa negara kecil yang kesulitan untuk mandiri secara ekonomi. 


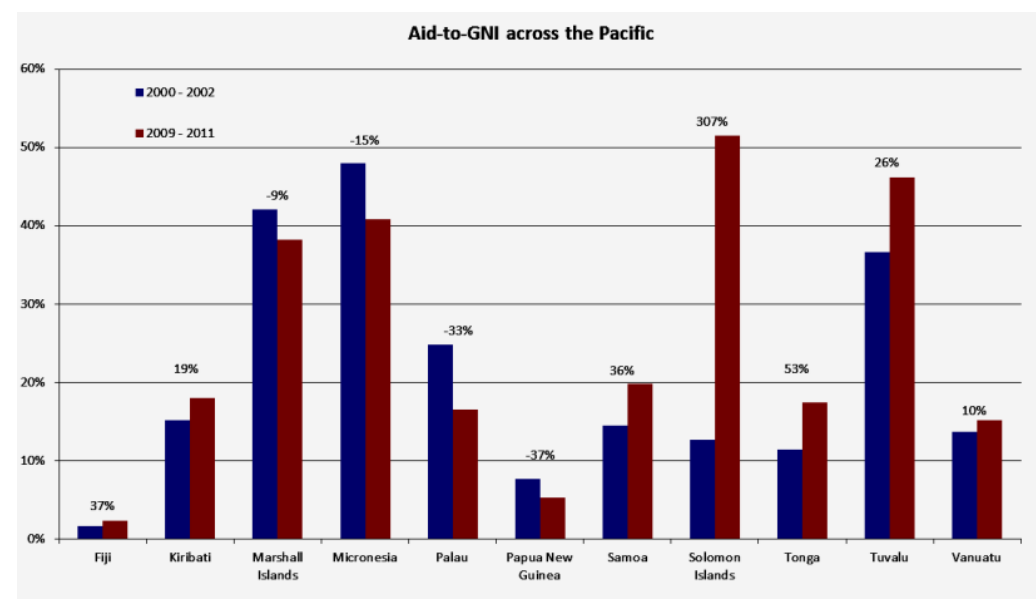

Sumber: Jonathan Pryke, 2013. http://devpolicy.org

Sekali pun demikian, terdapat kecenderungan perbaikan ekonomi sejak tahun 2010. Beberapa negara mengalami pertumbuhan ekonomi di atas empat persen. Perkembangan ini menarik, sekalipun belum bisa dijadikan indikasi sustainability pertumbuhan di semua negara dan belum pula dapat menjadi indikasi bagi negara-negara MSG (tanpa Indonesia).

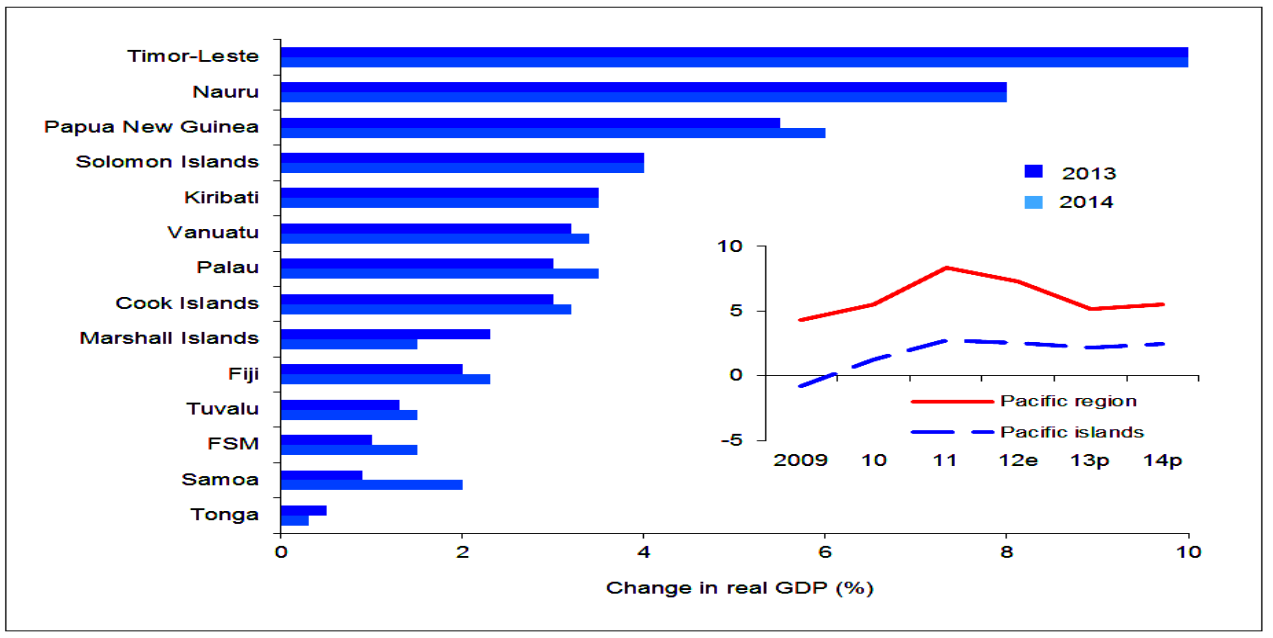

Sumber: Christopher Edmonds, 2013. Sumber: Pryke, Jonathan. 2013.

http://devpolicy.org

Momentum pertumbuhan ekonomi yang cukup tinggi perlu dipertahankan untuk meningkatkan kemandirian dan mengurangi ketergantangan pada bantuan asing. Untuk mencapai tahap ini negaranegara Pasifik, khususnya sub kawasan Melanesia memerlukan langkah- 
langkah strategis. Dalam kaitan ini MSG dapat mengambil peran penting melalui serangkaian tindakan transformasi dari organisasi yang mengedepankan identitas menjadi organisasi yang memperkuat integrasi ekonomi, yang pada dasarnya merupakan tujuan awal terbentuknya MSG. MSG dapat menjadi regionalisme yang lebih fungsional dan dapat mengangkat martabat negara anggotanya menjadi sekelompok negara yang tidak terlalu bergantung pada bantuan asing. Apabila MSG mampu memperkuat dimensi ekonominya, MSG dapat menjadi mekanisme regional yang berfungsi tidak hanya memfasilitasi terbentuknya we-feeling, tetapi mendayagunakan we-feeling untuk menciptakan area perdagangan yang kondusif untuk kemajuan pembangunan di kawasan.

MSG telah menampakkan pergeseran dari komunitas politik yang kental dengan dimensi etnis dan identitas menjadi kawasan yang mengutamakan perdagangan bebas sejak tahun 2000-an, walaupun pada dasarnya MSG Free Trade Agreement (FTA) telah terbentuk pada tahun 1993. MSG FTA beranggotakan negara-negara yang berkomitmen untuk saling member status 'most favoured nations' (MFN) yang membari kemudahan bagi negara bukan anggota MSG, terutama negara-negara Pasifik Selatan lainnya. Penetapan Konstitusi MSG tahun 2007 dan Sekretariat pada tahun 2008 di Port Villa, Vanuatu menandai babak baru MSG sebagai wadah kerjasama yang lebih menguntungkan di antara sesama negara anggotanya. Langkah MSG semakin jelas bergerak dari wadah kerjasama politik menuju integrasi ekonomi yang lebih solid, yang memberi kesempatan anggotanya memperkuat pertumbuhan ekonomi (PiPP 2008). Dengan makin beragamnya kegiatan MSG, organisasi ini telah mengukuhkan diri menuju sebuah integrasi ekonomi regional penting. Selain MSG FTA, ada sejumlah proyek dan kegiatan berlangsung dalam beberapa kegiatan ekonomi, termasuk pengembangan skema pengembangan keterampilan untuk memfasilitasi migrasi tenaga kerja antar negara anggota. Pada KTT MSG tahun 2013, MSG mengambil langkah inovatif untuk mendirikan sebuah badan yang berfokus pada operasi penjaga perdamaian (peacekeeping force) untuk menyediakan personil keamanan bagi misi-misi penjaga perdamaian PBB di berbagai tempat lain di dunia (The Lowy Interpreter 2014).

\section{Simpulan}

Inisiatif kelahiran banyaknya organisasi regional di Pasifik Selatan sebagian besar didorong oleh ketidakpuasan beberapa negara atas sikap negara-negara metropolitan (mantan penguasa) yang terkesan terlalu banyak mengontrol masa depan negara-negara Pasifik. Bersamaan dengan semakin berkembangnya dinamika geopolitik dan geoekonomi, negara-negara Pasifik menunjukkan keinginan besar untuk lebih 
mandiri, yang salah satu caranya adalah dengan mendirikan pengelompokan regional yang digerakkan oleh mereka sendiri. Inisiatif ini merupakan pendekatan baru yang bertujuan untuk mencari penentuan nasib sendiri melalui mekanisme regionalisme yang dapat diterjemahkan sebagai sikap anti-kolonisasi negara-negara Pasifik.

Di tengah situasi yang kondusif pulalah MSG muncul sebagai organisasi yang mampu menjawab berbagai persoalan ekonomi, politis dan sosiokultural yang dihadapi oleh Pasifik Selatan. Tidak lagi didominasi oleh isu-isu yang berorientasi primordial, MSG menghadirkan diri sebagai organisasi yang relevan untuk mengatasi kebuntuan dan membekunya aktivitas PIF. Perkembangan kelembagaan MSG menunjukkan evolusi regionalisme di Pasifik, manjadikan organisasi ini tidak terjebak dalam problematika yang tidak memberinya nilai lebih. Kehadiran MSG memberi energi baru yang menunjukkan pentingnya revitalisasi kerjasama regional di kawasan yang jauh dari pusaran politik global, namun secara potensial isu-isu yang berkembang di kawasan itu merepresentasikan berbagai isu global. Perkembangan paling menarik dari MSG adalah menguatnya keinginan negara-negara anggotanya untuk mewujudkan kemandirian regional. Tidak ada pilihan lain bagi mereka: sementara negara-negara metropolitan mulai meninggalkan kawasan ini, berbagai persoalan mendesak untuk diselesaikan. Sentimen etnisitas yang mewarnai awal berdirinya MSG tidak lagi produktif dijadikan sebagai basis kerjasama. MSG dapat mengambil manfaat dari meluasnya interaksi crossborder di dalam kawasan regional dalam mengembangkan berbagai kerjasama di antara mereka. Mobilitas crossborder dalam bidang perdagangan/ekonomi, sosial dan budaya dengan mengutamakan people to people contact, bisa menjadi agenda yang dinamis dan berkelanjutan (sustain). Hal ini penting untuk mengurangi stigma tentang kompleksitas persoalan yang bertumpangtindih di Pasifik Selatan. Pergeseran sifat regionalisme, penguatan dan perluasan bidang kerjasama di dalam MSG merupakan signal positif dalam perkembangan regionalisme di Pasifik Selatan.

Dalam kaitan ini, bergabungnya Indonesia dalam MSG semestinya dapat dijadikan tonggak penting bagi MSG untuk move on menjadi organisasi yang lebih fungsional. Di sisi yang lain, Indonesia pun semestinya pula mampu mendayagunakan keanggotaannya di MSG untuk berbagai kepentingan yang tidak saja bersifat politis, namun juga ekonomi dan kultural. Sudah saatnya pula bagi Indonesia untuk memanfaatkan posisi geokulturalnya sebagai bagian dari Pasifik untuk berperan asertif dslam mengembangkan berbagai kerjasama dengan negara-negara Pasifik, yang selama beberapa dekade hanya menempati posisi marginal dalam politik luar negeri Indonesia. 


\section{Daftar Pustaka}

\section{Buku}

Fairbairn, Te'o I.J. at al. 1991. The Pacific Islands: Politics, Economics, and International Relations. Honolulu, the University of Hawaii Press.

\section{Briefing Paper}

Pacific Institute of public Policy (PiPP), 2008. MSG: Trading on Political Capital and Melanesian Solidarity. Briefing Paper no.2. Port Villa, PiPP.

\section{Jurnal Ilmiah}

Tarte, Sandra. "Regionalism and Changing Regional Order in the Pacific Islands", Asia and the Pacific Policy Studies, 1 (2): 312-324.

Saideman, Stephen M. 2002. "Discrimination in International Relations: Analyzing External Support for Ethnic Groups". Journal of Peace Research, 39, (1), 2002: 27-50.

Vanhanen, Tatu. 1999. "Domestic Ethnic Conflict and Ethnic Nepotism: A Comparative Analysis". Journal of Peace Research, 36, (1): 5573 .

\section{Internet}

ANU, nd. Pacific Island Forum [online]. http://press.anu.edu.au/wpcontent/uploads/2011/o5/o42.pdf) [diakses 23 Oktober 2015].

Edmonds, Christopher, 2013. PNG slowdown pushing regional growth lower in the Pacific in 2013 [online]. http://devpolicy.org. [diakses 12 Oktober 2014].

Frazer, Ian and Bryant-Tokalau, Jenny. Introduction: The Uncertain Future of Pacific Regionalism [online]. https://www.ashgate.com/pdf/SamplePages/Redefining_the_Pacifi c_Intro.pdf. [diakses 23 Oktober 2015].

Kaiku, Patrick. 2013. How Relevant is the Melanesian Spearhead Group? [online] http://pacificpolicy.org/blog/2013/o3/27/how-relevant-inthe-melanesian-spearhead-group/ [diakses 2 Oktober 2014].

Pryke, Jonathan. 2013. The Pacific's Aid Boom [online]. http://devpolicy.org. [diakses 12 Oktober 2014].

Shibuya, Eric. nd. The Problems and Potential of Pacific Islands Forum [online]. 
http://apcss.org/Publications/Edited\%2oVolumes/RegionalFinal\% 20chapters/Chapter7Shibuya.pdf [diakses 13 Oktober 2015].

Tarcisius Kabutaulaka , 2015. West Papua: MSG's challenge, Indonesia's Melanesian foray [online]. http://dailypost.vu/news/west-papuamsg-s-challenge-indonesia-s-melanesian-foray/article_oacf8acbbd32-54db-8d6c-9fafbf83373f.html. [diakses 30 September 2015].

The Lowy Interpreter. 2014. The Melanesian Spearhead Group: What is it, and what does it do? [online] http://www.lowyinterpreter.org/post/2014/o3/14/TheMelanesian-Spearhead-Group-What-is-it-and-what-does-itdo.aspx?COLLCC $=1148345892 \&$ [diakses 3 Oktober 2014].

UNESCAP. 2000. Climate Change and the Pacific Islands. [online] http://www.unescap.org/meed200o/pacific/background/climate.ht m. [diakses 15 September 2009]

Lawson, Stephanie, 2012. Ethnic Identity and Regionalism in the Southwest Pacific: The Melanesia/Polynesia Divide in Contemporary Politics [online]. Paper prepared for presentation to RC 14, Politics and Ethnicity, International Political Science Association XXIInd World Congress, Madrid, 8-12 July 2012. http://paperroom.ipsa.org/app/webroot/papers/paper_15421.pdf [diakses 12 Agustus 2015]. 